Biol. Stud. 2012: 6(3); 247-252 • DOI: https://doi.org/10.30970/sbi.0603.230

www.http://publications.Inu.edu.ua/journals/index.php/biology

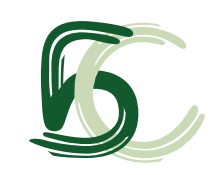

UDC 577.13:581.13

\title{
THE CYCOCEL EFFECT ON FLAVONOIDS CONTENT AND PHENYLALANINE AMMONIA-LYASE (PAL) ACTIVITY IN BUCKWHEAT (FAGOPYRUM ESCULENTUM Moench.) PLANT
}

\author{
O. Smirnov, A. Kosyan, O. Kosyk \\ Taras Shevchenko National University of Kyiv, 64, Volodymyrska St., Kyiv 01033, Ukraine \\ e-mail: mcd_smirnov@mail.ru
}

Flavonoids are important secondary plant metabolites with many and diverse key functions that belong to largest class of substances produced by plants - phenylpropanoids. These substances are of interested among plant and animal biochemists, plant pathologists, geneticists and biotechnologists. Flavonoids rutin and anthocyanin as herbal compounds characterized by physiological activity of a wide action spectrum: antiulcer, vitamin, antioxidant, stabilizing, ultraviolet radiation protecting, antitumor, tannic, etc. Therefore much attention has been attracted to biosynthesis of flavonoids and methods of its regulation and controlling. We determined concentration (2\%) of growth regulator Cycocel (chlormequat chloride, CCC) that significantly raised anthocyanin and rutin levels in buckwheat (Fagopyrum esculentum Moench.) plants. Thin-layer chromatography revealed an increase in total flavonoids content in leaves of test plants, which was: by 3.5 times for rutin and by 8 times for anthocyanin. The same concentration of CCC had induced phenylalanine ammonia-lyase activity by 2 times. Moreover, an increase in the flavonoids content correlated with enzyme activity induction. Thus, the growth regulator Cycocel is an activator of flavonoids metabolism. Treatment by CCC significantly increased content of secondary flavonoid metabolites and activity of phenylalanine ammonia-lyase - flavonoids biosynthesis regulatory enzyme.

Keywords: Fagopyrum esculentum, flavonoids, rutin, anthocyanins, Cycocel.

\section{INTRODUCTION}

To date proved that flavonoids belong to a large class of plant phenylpropanoids. They are involved in major processes of plant organisms such as cell walls formation, photosynthesis, respiration, plant-plant allelopathic interactions, protection plants against pathogens and herbivores both insects and mammals [10]. They are produced by plants in response to biotic or abiotic stresses such as wounding, UV-radiation, exposure to pollutants, ozone, and other hostile environmental conditions [9, 20].

Flavonoids also have a practical importance. Food and light industry technological processes are based on their oxidative transformations [12]. 
Flavonoids (rutin and anthocyanins) are herbal remedies and successfully applied in medical technology [11]. The most important characteristic of flavonoids in health effects is a high level of physiological activity with wide range of action [16].

Today we have achieved a significant progress in research of flavonoids chemical structure, biosynthesis, and intracellular localization. It is known that they are produced through cinnamic acid by phenylpropanoid pathway, next reactions are also well known $[3,4,7]$.

The results of research by Harborne (2000) [15] indicated that vegetative mass of buckwheat (Fagopyrum esculentum Moench.) is a potential source of biologically active substances. Rutin and anthocyanins were found in the above-ground organs of buckwheat - leaves, inflorescences, hypocotyls [18].

\section{MATERIALS AND METHODS}

Source of plant materials. Buckwheat seeds (Fagopyrum esculentum Moench. var Rubra) were treated by Cycocel for selection of active substance concentration $(0.5 \%, 1 \%, 2 \%)$. As the control variant distilled water was used. Buckwheat shoots were grown in the greenhouse with supplemental fluorescent lights by the sand culture. A light period of 16 hours was maintained. Plants were irrigated with Knop's nutrient solution ( $\mathrm{pH}$ 5.8). Experiments were carried out with thirty day shoots. For flavonoids and enzyme assay were used randomly chosen leaves.

Rutin estimation. The samples were fixed at $105^{\circ} \mathrm{C}$ for $15 \mathrm{~min}$ and put into the drying oven at $40^{\circ} \mathrm{C}$ for dry matter obtaining. Buckwheat leaves (50-100 mg) of each sample were homogenized in $0.2 \mathrm{~g}$ glass powder. Homogenate was transferred in testtube and added $2 \mathrm{~mL}$ methanol. The mixture kept for 1 hour for extraction. After 1 hour the mixture was centrifuged at $3000 \mathrm{~g}$ for $5 \mathrm{~min}$. The supernatant used for the next steps of rutin analysis.

Series of standard solutions of rutin and quercetin (concentrations $0.5,1,2,4 \mathrm{mg} /$ $\mathrm{ml}$ ) and $0.5 \mu \mathrm{l}$ extract were dropped on the plate with silicagel (Sorbfil). The chromatogram was placed in the S-chamber. The solvent system for the separation of flavonoid compounds was ethyl acetate - acetonitrile - 35\% formic acid (13:5:2, v/v/v). After drying the plates with a hot air stream, visualization was performed by sprinkling with a $0.1 \% \mathrm{TiOSO}_{4}$; chromatograms were interpreted in wavelength $450 \mathrm{~nm}$ [18].

The rutin content was determined by formula: $X=\frac{C \times V}{a}$ where, $\mathrm{X}$ - rutin content in the samples, $\mathrm{mg} \times \mathrm{g}^{-1} ; \mathrm{C}$ - rutin concentration according to calibration, $\mathrm{mg} \times \mathrm{ml}^{-1} ; \mathrm{a}-$ weight of plant material, $\mathrm{g}$.

Anthocyanin estimation. The quantitative content of anthocyanin pigment was defined by using differential spectrophotometry with $\mathrm{pH}$ factor [13]. The anthocyanins content was measured at 510 and $700 \mathrm{~nm}$. Quantity of anthocyanin was calculated with using cyanidin-3-glucoside coefficients (molar extinction coefficient of $26900 \mathrm{~L} \mathrm{~cm}^{-1}$ $\mathrm{mol}^{-1}$ and molecular weight of $\left.449.2 \mathrm{~g} \mathrm{~mol}^{-1}\right)$.

Phenylalanine ammonia-lyase activity assay. The phenylalanine ammonia-lyase (PAL) activity was determined by method modified from Zucker [22]. The spectrophotometric determination of PAL based on changes of absorbance at $290 \mathrm{~nm}$.

For enzyme analysis $0.2 \mathrm{~g}$ of leaves were homogenized in $1 \mathrm{ml} 25 \mathrm{mM}$ borate buffer (pH 8.8) containing $23 \mu \mathrm{L}$ of mercaptoethanol. The homogenates were centrifuged for

ISSN 1996-4536 • Біологічні Студії / Studia Biologica • 2012 • Том 6/№3 • С. 247-252 
$20 \mathrm{~min}$ at $8000 \mathrm{~g}$. The supernatant was used for enzymatic assay. The PAL assay system contained of $1 \mathrm{ml}$ of the supernatant, $1 \mathrm{ml}$ of buffer, $1 \mathrm{ml}$ of $12 \mathrm{mM} \mathrm{L}$-phenylalanine. The resulting mixture was heated at $37^{\circ} \mathrm{C}$ for 1 hour. The reaction was stopped by $15 \%$ trichloroacetic acid. Absorbance of the mixture was measured using spectrophotometer "CФ 46". Results of measuring PAL activity were expressed in $\mathrm{mM}$ of cinnamic acid per gram of protein. Protein was determined by of Lowry method [21].

Statistical analysis. Each experiment was repeated three times. The means and standard deviations were calculated by the Microsoft Office Excel. Statistical significance of difference was evaluated with Student's t-test $(P<0.05)$.

\section{RESULTS AND DISCUSSION}

Plant growth regulator chlormequat chloride (Cycocel, CCC) acts by inhibiting gibberellin biosynthesis, reduces unwanted longitudinal shoot growth without lowering plant productivity. Cycocel is used extensively to reduce lodging of wheat, and to reduce vegetative growth of cotton. CCC is known as protection system activator in plant under oxidative stress. Processing by CCC led to increasing photosynthetic, UV-protective pigments and flavonoids content [1]. Understanding of Cycocel influencing mechanisms on flavonoids biosynthesis is important for plant physiology, pharmacy and drug design.

The results of our investigation showed that treatment by Cycocel induced an increase of flavonoids level in buckwheat shoots.

Analysis of flavonoids content revealed the most effective growth regulator concentration $-2 \%$. This concentration significantly raised rutin and anthocyanins content. Wide variation in the levels of both rutin and anthocyanins in buckwheat plant was detected: by 3.5 times for rutin and by 8 times for anthocyanins (see Fig. 1).

Fig. 1. The Cycocel effect on flavonoids content in leaves of 30-day buckwheat shoots; * $-\mathrm{P}<0.05$

Рис. 1.Вплив хлорхолінхлориду на вміст фрлавоноїдів у листках 30-денних проростків гречки звичайної; * $-\mathrm{P}<0,05$

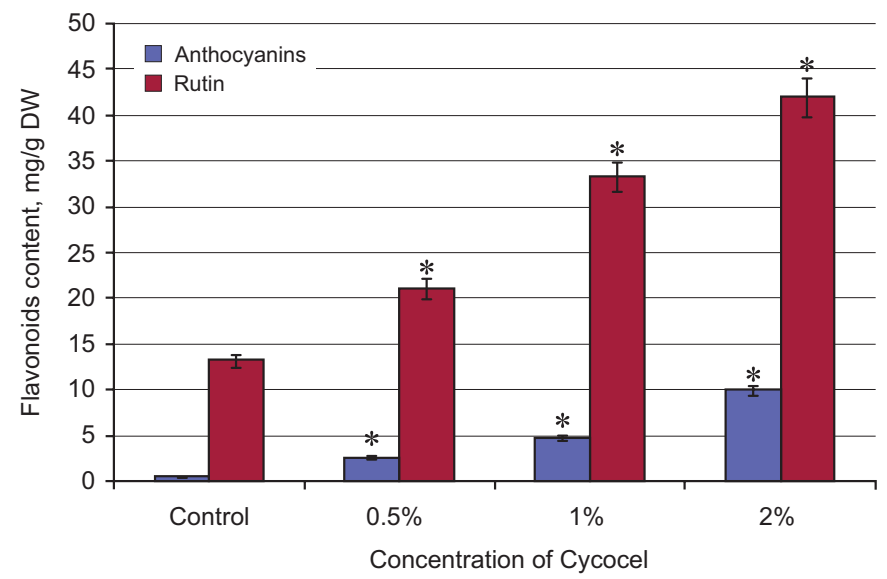

The carbon skeleton of all flavonoids is synthesized by phenylpropanoid pathway. Dezamination of L-phenylalanine to cinnamic acid is the first reaction of phenylpropanoid pathway which catalyzed by phenylalanine ammonia-lyase (PAL, EC 4.3.1.5) [3, 5].

This enzyme was first discovered by Koukol and Conn (1961) [19] and has since been found in a wide variety of plants [8]. PAL has been on focus of interest not only for its role in plant phenolic metabolism, but because its activity fluctuates significantly in plant issues in response to a variety of physical and chemical stimuli $[8,9]$. 
Several factors are known to affect the expression and activity of PAL. They are light, wounding [14], disease, gamma-ray irradiation, germination, development and differentiation, and the application of certain macromolecules [17]. Zucker (1972), Camm and Towers (1973), Margna (1977) [8, 22, 24] determined PAL activity such as the most limiting factor in the biosynthesis of flavonoids and other phenylpropanoids.

Our data showed that $2 \%$ concentration of growth regulator induced PAL activity by 2 times (see Fig. 2).

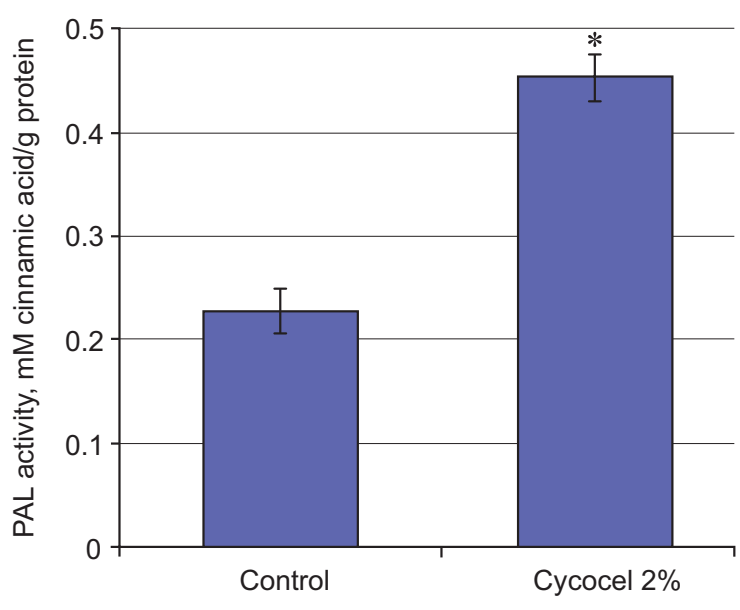

Fig. 2. The Cycocel effect on phenylalanine ammonia-lyase activity in leaves of 30-day buckwheat shoots; * $-\mathrm{P}<0.05$

Рис. 2. Вплив хлорхолінхлориду на активність фенілаланін аміак-ліази в листках 30-денних проростків гречки звичайної; * - P $<0,05$

Moreover, an increase in the flavonoids content correlated with PAL activity stimulation. Quantitative analysis of the results confirmed that. Correlation coefficient for rutin was 0.946 and for anthocyanins 0.938 , respectively.

The obtained results indicate that treatment of buckwheat (Fagopyrum esculentum Moench.) by growth regulator Cycocel (2\%) led to activation of phenolic metabolism, because rise of phenylalanine ammonia-lyase (regulatory enzyme) activity and secondary proved by flavonoid metabolites content.

1. Василенко В.Ф., Креславский В.Д., Кузнецов Е.Д. Хлорхолинхлорид как модификатор ряда регулируемых фитохромом процессов роста и фротосинтеза. Доклады АН СССР, 1991; 316(6): 234-236.

2. Иванов Л.В., Хаджай Я.И., Кошелёва Л.П. Сродство к биомембранам и некоторые особенности фармакокинетики соединений флавоноидной природы. Химико-фармацевтический журнал, 1992; 26(2): 20-23.

3. Олениченко Н.A., Загоскина Н.В. Ответная реакция озимой пшеницы на действие низких температур: образование фенольных соединений и активность L-фенилаланин аммиак-лиазы. Прикладная биохимия и микробиология, 2005; 41(6): 681-685.

4. Хайруллина В.Р. Экспериментальное и теоретическое исследование антирадикальной активности природных полифенолов: дис. канд. ... хим. наук: 02.00.04: Уфра, 2005. $180 \mathrm{c}$.

5. Яруллина Л.Г., Ибрагимов Р.И. Активность фенилаланин аммиак-лиазы и ингибиторов протеолитических ферментов в проростках пшеницы при септориозе. Физиология и биохимия культурных растений, 2000; 32(3): 223.

6. Andersen O.M., Markham K.R. Flavonoids Chemistry, Biochemistry and Applications. CRC Press, 2005. 1212 p.

ISSN 1996-4536 • Біологічні Студії / Studia Biologica • 2012 • Том 6/№3 • С. 247-252 
7. Burda S.W., Oleszek C.Y. Phenolic compounds and their changes in apples during maturation and cold storage. Agr. Food Chemistry Journ, 1990; 38: 945-948.

8. Camm E.L., Towers G.H.N. Phenylalanine ammonia-lyase. Phytochemistry, 1973; 12: $961-$ 973.

9. Dixon R.A., Paiva N.L. Stress-induced phenylpropanoid metabolism. Plant Cell, 1995; 7: 1085-1097.

10. Douglas C.J. Phenylpropanoid metabolism and lignin biosynthesis: from weeds to trees. Trends in Plant Science, 1996; 1: 171-178.

11. Erdman Jr. J. W., Balentine D., Arab L.G. Flavonoids and Heart Health. Journ. of Nutrition, 2007; 7: 32-36.

12. Gehm B.D., McAndrews J.M., Chien P.Y., Jameson L.J. Resveratrol, a polyphenolic compound found in grapes and wine, is an agonist of the estrogen receptor. Proc. Natl. Acad. Science, 1997; 94: 14138-14143.

13. Giusti M.M., Wrolstad R.E. Anthocyanins. Characterization and measurement with UV-visible spectroscopy. Current Protocols in Food Analytical Chemistry, 2001. 1.2: 1-13.

14. Guillet G., De Luca V. Wound-inducible biosynthesis of phytoalexin hydroxycinnamic acid amides of tyramine in tryptophan and tyrosine decarboxylase transgenic tobacco lines. Plant Physiol, 2005; 137(2): 692-699.

15. Harborne J.B., Williams C.A. Advances in flavonoid research since 1992. Phytochemistry, 2000; 55: 481-504.

16. Havsteen B.H. The biochemistry and medical significance of flavonoids. Pharmacol. Ther, 2002; 3: 67-202.

17. Hyodo Hiroshi, Shang Fa Yang. Ethylene-enhanced synthesis of phenylalanine ammonialyase in pea seedlings. Plant Physiol, 1971; 47: 765-770.

18. Kosyan A., Sytar O., Taran N. Anthocyanins as marker for selection buckwheat plants with high rutin content. Advances in buckwheat research. Proceedings of the 11-th International Symposium of Buckwheat, 2010; 314-319.

19. Koukol J., Conn E. The metabolism of aromatic phenylalanine deaminase of Hordeum vulgare. J. Biol. Chem, 1961; 236: 2692-2698.

20. Lavola A., Aphalo P.J., Lahti M. Nutrient availability and the effect of increasing UV-B radiation on secondary plant compounds in Scots pine. Environmental and Experimental Botany, 2003; 49: 49-60.

21. Lowry K., Rosebrough N.J., Farr A.Z. Protein measurement with the Folin phenol reagent. J. Biol. Chem, 1951; 193(1): 265-275.

22. Margna $U$. Control at the level of substrate supply an alternative in the regulation of phenylpropanoid accumulation in plant cells. Phytochemistry, 1977; 16: 419-426.

23. Zucker $M$. Induction of phenylalanine deaminase by light and its relation to chlorogenic acid synthesis in potato tuber tissue. Plant Physiol, 1965; 40: 779-784.

24. Zucker M. Light and enzymes. Annu. Rev. Plant Physiol, 1972; 23: 133-156.

\section{ВПЛИВ ХЛОРОХОЛІНХЛОРИДУ НА ВМІСТ ФЛАВОНОЇДІВ І АКТИВНІСТЬ ФЕНІЛАЛАНІН АМІАК-ЛІАЗИ (ФАЛ) У РОСЛИНАХ ГРЕЧКИ ЗВИЧАЙНОЇ (FAGOPYRUM ESCULENTUM Moench.)}

О. Смірнов, А. Косян, О. Косик

Київський національний університет імені Тараса Шевченка вул. Володимирська, 64, Київ 01033, Україна e-mail: mcd_smirnov@mail.ru

Флавоноїди - клас поліфункціональних рослинних вторинних метаболітів, які належать до групи френілпропаноїдів. Широке застосування фрлавоноїдів як біологічно активних речовин обумовлює значну зацікавленість ними біохіміків рослин 
і тварин, фрітопатологів, хіміків, генетиків та біотехнологів. Володіючи широким спектром дії (Р-вітамінним, противиразковим, ніпоазотермічним, антиоксидантним, стабілізуючим, дубильним, антипухлинним), ці сполуки є основою для багатьох лікарських засобів і біодобавок. Найбільш розповсюдженими та цінними для фрармацевтичної промисловості представниками класу $є$ рутин і антоціани. При цьому найбільш перспективним є напрям вивчення процесів регуляції біосинтезу фрлавоноїдів. У роботі виявлено, що обробка рослин гречки звичайної (Fagopyrum esculentum Moench.) 2\%-ною концентрацією регулятора росту хлорхолінхлориду (ССС) призводить до активації фрлавоноїдного метаболізму. Вміст рутину збільшується у 3,5 разу, антоціанів - у 8 разів. Ця концентрація підвищує активність регуляторного фрерменту фрлавоноїдного синтезу фенілаланін аміак-ліази у 2 рази.

Ключові слова: Fagopyrum esculentum, фрлавоноїди, рутин, антоціани, хлорхолінхлорид.

\title{
ВЛИЯНИЕ ХЛОРХОЛИНХЛОРИДА НА СОДЕРЖАНИЕ ФЛАВОНОИДОВ И АКТИВНОСТЬ ФЕНИЛАЛАНИН АММИАК-ЛИАЗЫ (ФАЛ) В РАСТЕНИЯХ ГРЕЧИХИ ОБЫКНОВЕННОЙ (FAGOPYRUM ESCULENTUM Moench.)
}

\author{
А. Смирнов, А. Косян, О. Косык \\ Киевский национальный университет имени Тараса Шевченко \\ ул. Владимирская, 2, Киев 01033, Украина \\ e-mail: mcd_smirnov@mail.ru
}

Флавоноиды - класс полифункциональных растительных вторичных метаболитов, которые относятся к группе фенилпропаноидов. Эти биологически активные вещества представляют интерес для биохимиков растений и животных, фритопатологов, химиков, генетиков и биотехнологов. Обладая широким спектром действия (Р-витаминным, противоязвенным, нипоазотермичным, антиоксидантным, стабилизирующим, антиопухолевым, дубильным), данные вещества нашли широкое применение в фармации в качестве основы для лекарственных средств и биодобавок. Наиболее распространенными и ценными в этом классе веществ являются рутин и антоцианы. При этом наибольший интерес вызывает изучение процессов регуляции биосинтеза флавоноидов. В работе выявлено, что обработка растений гречихи обыкновенной (Fagopyrum esculentum Moench.) 2\%-ной концентрацией регулятора роста хлорхолинхлорида (ССC) приводит к активации флавоноидного метаболизма. Содержание рутина увеличивается в 3,5 раза, антоцианов - в 8 раз. Данная концентрация повышает активность регуляторного фрермента фрлавоноидного синтеза фенилаланин аммиак-лиазы в 2 раза.

Ключевые слова: Fagopyrum esculentum, фрлавоноиды, рутин, антоцианы, хлорхолинхлорид.

Одержано: 06.07.2012

ISSN 1996-4536 • Біологічні Студії / Studia Biologica • 2012 • Том 6/№3 • С. 247-252 